\title{
NUTRITIONAL STATUS AND HEALTH-RELATED QUALITY OF LIFE IN ADULT PATIENTS WITH CELIAC DISEASE

\author{
Yeliz Serin $^{1}$, Gamze Akbulut ${ }^{2}$
}

\begin{abstract}
:
Objective: This study evaluated the effect of nutrition on health-related quality of life in adult celiac patients.

Material-Methods: A total of 103 individuals (26 males and 77 females) diagnosed with celiac disease by a physician, registered in the Ankara Celiac Society, and between 20 and 50 years old were enrolled in the study. Research data was collected using the face-to-face survey method with the "Celiac Disease in Health-Related Quality of Life Survey" to evaluate participants' quality of life. Patient nutrient intake was determined using the 24-hour dietary recall method.

Results: The mean age of the patients was $37.5 \pm 8.89$ years and the age at diagnosis was $31.0 \pm 11.85$ years. The body mass index value was $22.7 \pm 3.57 \mathrm{~kg} / \mathrm{m}^{2}$. When the nutritional status of the participants was evaluated, the energy received from carbohydrates and protein was less, whereas the energy received from fat was more than the general recommendations. When the total quality of life score was evaluated, the average scores of men were higher than women (146.6 $\pm 17.51 \mathrm{vs.} 123.7 \pm 24.78)$. In addition, the total and subscale quality of life scores varied by gender, comorbid conditions, compliance with a gluten-free diet, and the duration of the gluten-free diet.

Conclusions: Celiac is a disease that requires a lifelong gluten-free diet. Most celiac patients have nutritional deficiencies and poor quality of life standards. In order to prevent these deficiencies, commercially prepared foods should be enriched, especially in vitamins and minerals. In addition, increasing awareness of celiac disease in society positively affects the quality of life of individuals.
\end{abstract}

UDC Classification: 613.2; DOI: http://dx.doi.org/10.12955/cbup.v6.1277

Keywords: Celiac, gluten free, diet, quality of life, adult, nutrition.

\section{Introduction}

Celiac disease is an autoimmune disease triggered by the ingestion of gluten, a protein found in wheat, barley, rye, and oats, and leads to damage of the small intestine in genetically susceptible individuals (Demirçeken, 2011). The prevalence of celiac disease in developed countries is approximately $0.5-1 \%$. With the influence of environmental factors, this rate is increasing worldwide (Zarkadas et al., 2013). In Turkey, the prevalence of celiac disease is estimated to be between 0.3 and $1 \%$ ("Celiac and celiac prevalence" 5/10/2015). Previous studies on different age groups have shown that the prevalence of celiac disease was $0.47 \%$ in a survey involving 20,190 school children (Dalgic et al., 2011). In a survey conducted by Elsürer et al. (2005) with tissue transglutaminase antibody positivity, the prevalence of celiac disease was $1.3 \%$ in the Turkish population (Elsurer et al., 2005). A gluten-free diet is the only effective treatment for celiac disease, as there are currently no medications that can reliably and safely prevent the mucosal damage caused by exposure to gluten (Nadhem et al., 2015). However, for many patients it is very difficult to adhere to a gluten-free diet for life (Samasca et al., 2014). The rate of adaptation of individuals to a gluten-free diet varies from $42 \%$ to $91 \%$ (Hall et al., 2009). Some nutritional deficiencies are detected in patients with celiac disease who adhere to gluten-free diets for a long time. Particularly due to the elimination of carbohydrate and grain sources in the diet, deficiencies occur in B vitamins and fiber intake (Thompson et al., 2005). Frequently, there is also a decrease in vitamin $\mathrm{D}$, vitamin $\mathrm{B}_{12}$, and folic acid levels in patients because of intestinal mucosa destruction (GarcíaManzanares \& Lucendo, 2011). Gluten-free diets can also affect the quality of life of individuals. A study conducted by Zarkadas et al. (2012) in the USA on adult celiac patients found that inadequate nutrition label information and out-of-home eating were common problems along with feelings of "deprivation and isolation" (Zarkadas et al., 2013). In another study conducted in the USA, celiac patients evaluated their general health condition as "poor" (Lee et al., 2012). In particular, the patients living in rural areas report barriers to compliance to the gluten-free diet. Perceived barriers for compliance include limited access to dietitians as well as the limited availability and high cost of glutenfree products (Goodyer et al., 2016).

Previous research focused on nutritional deficiencies in patients with celiac disease. In addition, the social, psychological, economic, and health-related quality of life of celiac patients has been studied.

\footnotetext{
${ }^{1}$ Department of Nutrition and Dietetics, Gazi University, Faculty of Health Sciences, Turkey, dytyelizserin@gmail.com

${ }^{2}$ Department of Nutrition and Dietetics, Gazi University, Faculty of Health Sciences, Turkey, dytgamzea@gmail.com
} 
However, there is not a wide range of community-based surveys for investigating nutritional status and health-related quality of life for adult celiac patients in Turkey. The aim of this study was to evaluate the effect of nutritional status on health-related quality of life in adult celiac patients living in Ankara, the capital city of Turkey. Therefore, determination of nutritional status and quality of life of celiac patients who live in a metropolis could contribute to future regulations and activities.

\section{Data and Methodology}

Individuals registered in the Ankara Celiac Association, aged 20-50 years, diagnosed by an expert doctor, and following a gluten-free diet for at least 6 months were eligible to take part in the survey. The study protocol was approved by the Gazi University Ethics Committee according to principles of the Declaration of Helsinki (World Medical Association, 2001). This study is descriptive and crosssectional. The "survey method" was used as the data collection method. All forms and questionnaires were answered in face-to-face interviews with the patients by the researcher at the Ankara Celiac Association. In order to determine the daily food consumption status of celiac patients, the 24-hour recall method was used. The average energy and macronutrient values consumed were calculated by BeBIS (Nutritional Information System) nutrition consumption program (BeBİS). A disease specific questionnaire was used for the measurement of health-related quality of life. The celiac disease questionnaire (CDQ) was developed and validated by Häuser et al. (2007) for adult patients (Häuser et al., 2007). The CDQ includes 28 items related to four subscales (emotion, social, worries, and GI) and evaluated on a 7-point Likert scale in which "7" corresponds to the best and " 1 " to the worst state. The total score and each subscale score were calculated with the sum of the score attributed to each item. A higher score indicates a higher quality of life. The highest score possible was 196 points, with 49 points for each subscale (Aksan et al., 2015; Häuser et al., 2007; Marchese et al., 2013; Zampieron et al., 2011). The Turkish version of the CDQ was adapted and validated by Aksan et al. (Aksan et al., 2015).

\section{Statistical Analyses}

Statistical analyses were performed using SPSS software version 22.0. The variables were investigated using visual (histograms, probability plots) and analytical (Kolmogrov-Smirnow) methods to determine whether they were normally distributed. Descriptive analyses were presented using mean and standard deviation for normally distributed variables and medians and interquartile range (IQR) for non-normally distributed variables. The T-test, ANOVA test, and Mann-Whitney U test were used to compare proportions, means, or median scores in different groups. A p value of less than 0.05 was considered a statistically significant result.

\section{Results and Discussion}

Celiac is a lifelong health problem, which is a rare and difficult to diagnose disease in Turkey. There are no wide range community-based research studies conducted in Turkey regarding the nutritional habits and quality of life of adult celiac patients ("Çölyak ve Görülme Sıklığı," 10.05.2015). Recent international studies show that celiac patients who cannot adapt to a gluten-free diet tend to have poor eating habits and low quality of living standards (Fera et al., 2003; Häuser et al., 2006; Lee et al., 2012; O'leary et al., 2002; Zarkadas et al., 2013). In the city of Ankara, prior to April 2015, 6,766 patients received a celiac diagnosis and the frequency of occurrence was $0.13 \%$, which has been registered in the information system of the Ministry of Health ("Celiac and celiac prevalence," 5/10/2015). In this study, nutritional status and health-related quality of life were compared for patients registered in the Ankara Celiac Association. This study was completed with 103 celiac patients ranging from 20 to 50 years of age ( 26 male and 77 female) (mean age $37.5 \pm 8.89$ years) medically diagnosed with celiac.

Celiac disease was first described as a disease mostly observed in children. However, it has been reported recently that celiac disease is more common in adults than in children, that the disease can occur in all age groups, and that over $20 \%$ of patients are over 55 years of age (Sáez et al., 2011). The age of diagnosis among adults varies from 40 to 60 years, and the vast majority of adult cases are women (Mukherjee et al., 2010). The mean age of celiac disease diagnosis was $31.0 \pm 11.85$ years in this study. 


\begin{tabular}{|l|c|c|c|c|c|c|c|}
\hline \multicolumn{2}{|l|}{ Table 1. Distribution of individuals according to anthropometric measurements } \\
\hline & \multicolumn{2}{|c|}{ Male (n=26) } & \multicolumn{2}{c|}{ Female (n=77) } & \multicolumn{2}{c|}{ Total (n=103) } & P* \\
\hline Measurement & $\overline{\mathbf{X}} \pm$ SS & Min-Max & $\overline{\mathbf{X}} \pm$ SS & Min-Max & $\overline{\mathbf{X}} \pm$ SS & Min-Max & \\
\hline Height $(\mathbf{c m})$ & $171.2 \pm 6.36$ & $155-180$ & $160.3 \pm 7.13$ & $145-178$ & $163.0 \pm 8.42$ & $145-180$ & \\
\hline Weight (kg) & $70.5 \pm 10.53$ & $49-90$ & $57.2 \pm 10.38$ & $40-89$ & $60.6 \pm 11.87$ & $40-90$ & \\
\hline BMI (kg/m $\left.{ }^{2}\right)$ & $23.9 \pm 2.89$ & $19.9-30.1$ & $22.3 \pm 3.69$ & $14.52-36.03$ & $22.7 \pm 3.57$ & $14.52-$ & 0.015 \\
& & & & & 36.03 & $* *$ \\
\hline
\end{tabular}

Classical celiac disease is an impairment of absorption for many years, usually considered in individuals admitted to various clinics due to growth retardation in children or loss of body weight in adults (Murray et al., 2004). However, recent studies show that the BMI in patients at baseline or later stages of celiac diagnosis are greater than the normal range $\left(18.5-24.9 \mathrm{~kg} / \mathrm{m}^{2}\right.$ ) (Balamtekin et al., 2011; Reilly et al., 2011; Whitehead, 2013). Therefore, individuals with normal or high BMI values may also be at risk for celiac disease (Kabbani et al., 2012). In a study comparing BMI values of celiac patients with healthy populations, mean BMI values of male patients were $21.6 \pm 2.9 \mathrm{~kg} / \mathrm{m}^{2}$ and mean BMI values of female patients were $23.1 \pm 4.0 \mathrm{~kg} / \mathrm{m}^{2}$, which is significantly lower than healthy participants (Olén, Montgomery, Marcus, Ekbom, \& Ludvigsson, 2009). In this study, BMI values of men were $23.9 \pm 2.89 \mathrm{~kg} / \mathrm{m}^{2}$ and of women were $22.3 \pm 3.69 \mathrm{~kg} / \mathrm{m}^{2}$ (Table 1). According to the Turkey Nutrition and Health Survey (2010) data, the average BMI in men and women over the age of 19 was $26.4 \pm 4.5 \mathrm{~kg} / \mathrm{m}^{2}$ and $28.9 \pm 6.4 \mathrm{~kg} / \mathrm{m}^{2}$, respectively (Turkey Nutrition and Health Survey, 2010). In both genders, the mean BMI values were pre-obese (BMI: 25.0-29.9 $\mathrm{kg} / \mathrm{m}^{2}$ ) according to the WHO BMI classification (World Health Organization regional office for Europe body mass index - BMI, 2018). The reason that the BMI values of celiac patients are lower than the general population may be due to the increased incidence of obesity in the general population (Onat et al.). However, newly diagnosed celiac disease individuals are expected to have low body weight because of mucosal injury (Singh et al., 2016). In this study, 64.1\% of celiac patients had normal BMI values according to the WHO classification and $22.3 \%$ of the group was pre-obese. The "compensatory hypothesis" proposed by Semeraro et al. (1986) explains why some individuals still have normal body weight despite mucosal damage to the small intestine due to celiac disease. According to this hypothesis, when damage occurs in the proximal part of the small intestine, the nutrient absorption capacity of the distal part of the intestine increases so that a compensatory mechanism develops in the small intestine. Findings supporting this hypothesis in celiac patients include higher villus length in the distal part of the small intestine, density of crypts, and number of epithelial cells than in normal patients (Semeraro, Barwick, \& Gryboski, 1986).

\begin{tabular}{|l|c|c|c|}
\hline Table 2. Distribution of daily consumption of energy and macronutrients according to gender \\
\hline Nutrients & Male (n=26) & Female (n=77) & P \\
\hline Energy (kcal)* & $\overline{\mathbf{X}} \pm$ SS or Median (IQR) & $\overline{\mathbf{X}} \pm$ SS or Median (IQR) & $0.017 * * *$ \\
\hline Total protein (g)* & $1547.3(676.49)$ & $1250.2(741.2)$ & $0.013 * * *$ \\
\hline Total protein (\%)* & $47.6(38.4)$ & $38.7(27.2)$ & 0.530 \\
\hline Total fat (g)* & $12.0(6)$ & $12.0(5)$ & $0.012^{* * *}$ \\
\hline Total fat (\%)** & $80.4(59.2)$ & $64.9(45.3)$ & 0.235 \\
\hline Carbohydrate (g)* & $47.2 \pm 8.46$ & $44.6 \pm 9.80$ & 0.110 \\
\hline Carbohydrate (\%)* & $148.6(97.9)$ & $132.3(94.5)$ & 0.574 \\
\hline Fiber (g)* & $43.0(10)$ & $42.0(15)$ & 0.492 \\
\hline$*$ Mann-Whitney U Test, **T-test, ***p<0.05, Source: Authors & $11.1(7.7)$ & \\
\hline
\end{tabular}

Inadequate macronutrient intake and some micronutrient deficiencies have been identified in newly diagnosed celiac disease patients not able to adequately adhere to gluten-free diets or receiving insufficient medical treatment (Kupper, 2005). One study reported 50\% of patients treated with a glutenfree diet for 10 years still had some nutritional deficiencies (Claes Hallert et al., 2002). In a study conducted by Barone et al. (2015), according to 7 days of food consumption records, the average daily energy intake of celiac patients was $1693.9 \pm 581.9 \mathrm{kcal}$ (Barone et al., 2015). In another study conducted by recording 3 days of food consumption in the USA, average daily energy intake of male patients was $2882 \pm 739 \mathrm{kcal}$ and average daily energy intake of female patients was $1900 \pm 401 \mathrm{kcal}$ (Thompson et al., 2005). In this study, the median energy intake of men and women was lower than the mentioned studies (1547.3 (676.49) and 1250.2 (741.2), respectively) (Table 2). Inadequate energy intake is also a sign of 
poor food intake (Kinsey, Burden, \& Bannerman, 2008). In a large number of celiac patients, there is decrease in carbohydrate intake levels in contrast to the increased level of fat intake (García-Manzanares \& Lucendo, 2011). A study conducted in the UK showed that energy received from carbohydrates, protein, and fats that contribute to daily energy use was approximately $49 \%, 18 \%$, and $31 \%$, respectively (Kinsey et al., 2008). Results of another study in Italy determined that energy from carbohydrates contributes to approximately $49.5 \%$ of daily energy use, fat was approximately $36.6 \%$, and protein was $13.3 \%$ (Dall'Asta, Scarlato, Galaverna, Brighenti, \& Pellegrini, 2012). This study revealed that ratios of carbohydrate, protein, and fat were $42.5 \%, 12 \%$, and $43.8 \%$, respectively (mean values both men and women) according to the daily food recall (Table 2). In the diets of celiac patients, the percentage of energy received from macronutrients are similar to the reference intervals suggested for healthy patients. The range of carbohydrates, protein, and fats that contributes to daily energy use should be 55-60\%, 15 $20 \%$, and $25-30 \%$, respectively (Saturni, Ferretti, \& Bacchetti, 2010). In the present study, energy received from carbohydrates and proteins were less whereas energy received from fat was more than recommended in celiac patients' diets. Barone et al. (2015) found that celiac patients' daily average intake of fat is $67 \pm 20.1 \mathrm{~g}$, which is relatively high compared to that of healthy individuals $(55.0 \pm 13.5$ g) (Barone et al., 2015). In this study, both male (80.4 (59.2) g) and female (64.9 (45.3) g) individuals' fat intake per day is quite high. This is not a surprising result because gluten-free products are reported to contain more fat than normal products (Miranda, Lasa, Bustamante, Churruca, \& Simon, 2014). In addition, limiting the sources of carbohydrates in diets can increase the ratio of energy that comes from fats (Baysal, 2009). In a study comparing daily fiber intake of celiac patients and healthy individuals, the daily fiber consumption of celiac patients $(7.3 \pm 4.9 \mathrm{~g})$ was significantly lower than that of healthy subjects (12.8 $\pm 4.4 \mathrm{~g})$ (Barone et al., 2015). Suggested daily amount of fiber intake for celiac disease is 25-35 g (Saturni et al., 2010). In this study, daily median fiber consumption for both men and women was 12.1 (13.6), 11.1 (7.7) respectively (Table 2). Various studies support the view that celiac patients' daily fiber intake is lower than general nutrition recommendations (Barone et al., 2015; Kupper, 2005; Reguła \& Śmidowicz, 2014). This may be because many gluten-free products are obtained from refined flour resulting in the loss of many nutrients, as well as the inability to enrich gluten-free products in nutrients, unbalanced dietary habits, and inappropriate food choices (Barone et al., 2015; Valente et al., 2015). In particular, the elimination of whole grain sources from the diet significantly affects the level of fiber intake.

Today, the only treatment for celiac disease is a lifelong gluten-free diet. Even if the gluten-free diet may provide an advantage to the individual in terms of managing their own treatment, it is not easy to change one's usual diet, especially for adult celiac disease pantients (Marion Zarkadas et al., 2006). There are some disadvantages of a gluten-free diet such as high food prices, a lower quality in product taste and texture, limited accessibility to the food, unpredictable gluten contaminations, and different cultural approaches related to foods (i.e. celebrations). This situation can cause significant social problems. Hence, celiac disease can significantly affect the health-related quality of life of individuals (Koehler, Wieser, \& Konitzer, 2014). In many studies, the health-related quality of life in celiac disease was associated with factors such as gender, age, marital status, education level, duration of illness, gastrointestinal system findings, gluten-free diet compliance, comorbid disease status, and age of diagnosis (C Hallert et al., 1998; Paarlahti et al., 2013; Sapone et al., 2012; Marion Zarkadas et al., 2006). In this study, health-related quality of life parameters of celiac patients were evaluated with similar variables. As a result, total quality of life scores and subscale quality of life scores (emotional, social, anxiety, and gastrointestinal) of men were statistically higher than those of women. In addition, the total quality of life scores of the individuals diagnosed during childhood adapted to the gluten-free diet, who adhered to a gluten-free diet for more than five years, and had no comorbid diseases were higher than the others (Table 3). In a study conducted in Italy, the quality of life of celiac patients was determined using the same quality of life scale (CDQ) and the patients' overall quality of life score was $150.9 \pm 26.80$ (Zampieron et al., 2011). In this study, total quality of life score of celiac patients was $129.5 \pm 25.15$ (Table 3 ). The quality of life of individuals can be influenced by sociodemographic and clinical features as well as economic factors. The limited availability and diversity of gluten-free foods as well as the high prices of these specialty foods makes it difficult to adapt to the diet, which can have a negative impact on quality of life (Bagolin do Nascimento, Medeiros Rataichesck Fiates, dos Anjos, $\&$ Teixeira, 2014). When the health-related quality of life (CDQ) scale items were evaluated, the greatest impact on total scores was "the cost of gluten-free products and financial distress in celiac disease 
treatments" (responses of patients: always $32.0 \%$, often $25.2 \%$ ) and the difficulty in obtaining glutenfree products (responses of patients: always $19.4 \%$, often $25.2 \%$ ). In this case, economic problems are the most important factor affecting the quality of life of celiac patients living in Turkey.

Table 3. Assessing health-related quality of life scores of individuals according to sociodemographic and clinical characteristics

\begin{tabular}{|c|c|c|c|c|c|c|}
\hline \multirow{2}{*}{\multicolumn{2}{|c|}{ Variables }} & \multicolumn{5}{|c|}{ Quality of Life Scores } \\
\hline & & $\begin{array}{c}\text { Emotion } \\
\mathbf{X} \pm \mathbf{S S}\end{array}$ & $\begin{array}{l}\text { Social } \\
\mathbf{X} \pm \mathrm{SS}\end{array}$ & $\begin{array}{c}\text { Worries } \\
\mathbf{X} \pm \mathbf{S S}\end{array}$ & $\begin{array}{c}\text { Gastrointestinal } \\
\qquad \mathbf{X} \pm \mathbf{S S}\end{array}$ & $\begin{array}{l}\text { Total quality of life } \\
\text { scores } \\
\mathbf{X} \pm \mathrm{SS}\end{array}$ \\
\hline \multirow{4}{*}{ Gender } & Male & $35.3 \pm 5.39$ & $40.5 \pm 5.22$ & $32.5 \pm 8.88$ & $38.2 \pm 3.76$ & $146.6 \pm 17.51$ \\
\hline & Female & $28.1 \pm 8.42$ & $34.6 \pm 6.95$ & $27.3 \pm 8.68$ & $33.5 \pm 7.70$ & $123.7 \pm 24.78$ \\
\hline & Total & $29.9 \pm 8.34$ & $36.1 \pm 7.02$ & $28.6 \pm 8.97$ & $34.7 \pm 7.21$ & $129.5 \pm 25.15$ \\
\hline & $\mathrm{P}$ value & $<0.001 *$ & $<0.001 *$ & $0.015^{*}$ & $0.001 *$ & $<0.001 *$ \\
\hline \multirow{4}{*}{$\begin{array}{l}\text { The age at } \\
\text { diagnosis } \\
\text { (years) }\end{array}$} & $\begin{array}{c}\text { Children (1- } \\
10)\end{array}$ & $32.2 \pm 7.62$ & $38.1 \pm 4.06$ & $36.3 \pm 8.04^{\mathrm{a}}$ & $37.2 \pm 8.36$ & $143.8 \pm 20.98^{\mathrm{a}}$ \\
\hline & $\begin{array}{l}\text { Adolescence } \\
\quad(11-18)\end{array}$ & $32.8 \pm 9.78$ & $40.3 \pm 3.32$ & $33.6 \pm 6.50^{\mathrm{a}}$ & $39.3 \pm 3.66$ & $146.2 \pm 13.62^{\mathrm{a}}$ \\
\hline & $\begin{array}{l}\text { Adulthood } \\
\qquad(+19)\end{array}$ & $29.5 \pm 8.33$ & $35.6 \pm 7.35$ & $27.4 \pm 8.72^{b}$ & $34.1 \pm 7.13$ & $126.7 \pm 25.34^{\mathrm{b}}$ \\
\hline & $\mathrm{P}$ value & 0.343 & 0.118 & $0.004 *$ & 0.079 & $0.030^{*}$ \\
\hline \multirow{3}{*}{$\begin{array}{l}\text { Comorbid } \\
\text { disease(s) }\end{array}$} & No & $33.5 \pm 7.10$ & $38.10 \pm 6.57$ & $31.76 \pm 9.09$ & $37.18 \pm 5.78$ & $140.5 \pm 22.04$ \\
\hline & Yes & $27.9 \pm 8.35$ & $35.04 \pm 7.06$ & $26.83 \pm 8.44$ & $33.26 \pm 7.59$ & $123.1 \pm 24.74$ \\
\hline & $P$ value & $0.001 *$ & $0.021 *$ & $0.007^{*}$ & $0.009 *$ & $0.000^{*}$ \\
\hline \multirow{3}{*}{$\begin{array}{l}\text { Adherence } \\
\text { to gluten- } \\
\text { free diet }\end{array}$} & Always & $30.65 \pm 7.91$ & $36.23 \pm 7.39$ & $30.83 \pm 9.56^{*}$ & $35.2 \pm 7.94$ & $133.0 \pm 26.14$ \\
\hline & Sometimes & $28.75 \pm 9.05$ & $36.05 \pm 6.35$ & $24.58 \pm 5.99$ & $33.6 \pm 5.52$ & $123.0 \pm 22.08$ \\
\hline & $\mathrm{P}$ value & 0.438 & 0.925 & $0.001 *$ & 0.179 & $0.049 *$ \\
\hline \multirow{4}{*}{$\begin{array}{l}\text { Duration of } \\
\text { adherence } \\
\text { to gluten- } \\
\text { free diet }\end{array}$} & $<1$ year & $27.9 \pm 9.44$ & $33.1 \pm 9.26^{\mathrm{a}}$ & $24.5 \pm 7.36^{\mathrm{a}}$ & $32.3 \pm 9.11$ & $117.8 \pm 31.58^{\mathrm{a}}$ \\
\hline & $1-5$ years & $30.5 \pm 8.43$ & $35.5 \pm 6.33^{\mathrm{a}, \mathrm{b}}$ & $27.6 \pm 8.73^{\mathrm{a}}$ & $35.2 \pm 5.51$ & $128.4 \pm 21.33^{\mathrm{a}, \mathrm{b}}$ \\
\hline & $>5$ years & $30.5 \pm 8.43$ & $38.8 \pm 5.96^{\mathrm{b}}$ & $32.3 \pm 9.04^{\mathrm{b}}$ & $34.9 \pm 8.13$ & $136.6 \pm 24.91^{\mathrm{b}}$ \\
\hline & $\mathrm{P}$ value & 0.575 & $0.023 *$ & $0.006 *$ & 0.557 & $0.036 *$ \\
\hline \multicolumn{7}{|c|}{$\begin{array}{l}* \mathrm{P}<0.05 \text {, for paired comparison T-test, for triple comparisons ANOVA test. }{ }^{\mathrm{a}, \mathrm{b}} \text { for groups marked with different letters, } \\
\mathrm{P}<0.05 \text { and for groups marked with the same letters, } \mathrm{P}>0.05 \\
\text { Source: Authors }\end{array}$} \\
\hline
\end{tabular}

In Italy, local healthcare establishments provide financial support (140-180 euros each month) for celiac patients to buy gluten-free products (Zampieron et al., 2011). Differences in the purchasing power for gluten-free products may cause lower quality of life scores for celiac patients who live in Turkey than other countries. Celiac disease was known as a disease observed in children. When individuals visit a hospital due to complaints, the time it takes for the tests to be performed and confusion with irritable bowel disease may cause the celiac diagnosis to be delayed (Alavinejad et al., 2014; Green \& Cellier, 2007). In a study assessing the effect of age on health-related quality of life, $83 \%$ of individuals were diagnosed after 20 years and those diagnosed at younger ages have higher quality of life scores than those diagnosed as adults (Norström, Lindholm, Sandström, Nordyke, \& Ivarsson, 2011). In this study, the total quality of life scores of the individuals diagnosed during childhood (143.8 \pm 20.98$)$ were higher than those diagnosed during adulthood (126.7 \pm 25.34$)$ (Table 3$)$. In a study conducted in Sweden, individuals diagnosed before 4 years of age were $80 \%$ more likely to adapt to a gluten-free diet (Högberg, Grodzinsky, \& Stenhammar, 2009). Among the reasons for the higher compliance to the diet of patients diagnosed during childhood are more knowledgeable and skillful in gluten-free food preparation, more accustomed to the taste of gluten-free foods, and more aware of the difficulties encountered during the diet (Biagetti, Naspi, \& Catassi, 2013). There is a strong association between gluten-free diet compliance and quality of life (Moiseenko, Osipenko, Ageeva, Krotov, \& Burbik, 2010). In this study, the total quality of life score of celiac patients who always followed a gluten-free diet were significantly higher than patients who sometimes followed the diet (Table 3). In a study evaluating the effect of time of adherence to gluten-free diet on health-related quality of life scores, individuals whose compliance to the diet was longer than 5 years have significantly higher quality of life scores than those whose compliance was less than 1 year (Pulido et al., 2013). In this study, the same time criteria had similar effects on total quality of life scores. However, remarkably, scores on the anxiety subscale of the CDQ showed that individuals who adhered to the diet longer than 5 years had higher anxiety scores than 
those who followed the diet for less than 1 year or 1-5 years (Table 3). A gluten-free diet affected the social life of patients and this situation could lead to higher anxiety scores.

\section{Conclusion}

Celiac is a disease that requires lifelong adherence to a gluten-free diet. Most celiac patients have nutritional deficiencies and poor quality of life standards. Adequate energy, macronutrients, micronutrients, and fiber needs of celiac patients are not always met by a gluten-free diet. In order to prevent these deficiencies, commercially prepared foods should be enriched, especially in the B and D group vitamins, fiber, iron, folate, and calcium. In addition, increasing awareness of celiac disease in society positively affects the quality of life of individuals. For this purpose, it will be useful to plan and carry out various activities and awareness campaigns by health personnel, public institutions and organizations, non-governmental organizations, and celiac associations. In addition, the role of individual education is very important in the formation of social awareness.

\section{References}

Aksan, A., Mercanlıgil, S.M, Häuser, W. and Karaismailoğlu, E. (2015). Validation of the Turkish version of the celiac disease questionnaire (CDQ). Health and Quality of Life Outcomes, 13(82), 1-7.

Alavinejad, P., Hajiani, E. Masjedizadeh, R., Hashemi, S., J., Faramarzi, M. and Sebghatollahi, V. (2014). Epidemiologic and Demographic Survey of Celiac Disease in zestan Province, Middle East Journal of Digestive Diseases, 6(2), 98-103.

Bagolin do Nascimento, A., Medeiros Rataichesck Fiates, G., dos Anjos, A., \& Teixeira, E. (2014). Availability, cost and nutritional composition of gluten-free products. British Food Journal, 116(12), 1842-1852.

Balamtekin, N., Demir, H., Baysoy, G., Uslu, N. and Yüce, A. (2011). Obesity in adolescents with celiac disease: two adolescents and two different presentations. The Turkish Journal of Pediatrics, 53, 314-316.

Barone, M., Della-Valle, N., Rosania, R., Facciorusso, A., Trotta, A., FP., Cantatore, F.P., Falco, S., Pignatiello, S., Viggiani, M.T., Amoruso, A., De Filippis, R., Di Leo, A., and Francavilla, R. (2015). A comparison of the nutritional status between adult celiac patients on a long-term, strictly gluten-free diet and healthy subjects. European Journal of Clinical Nutrition, 70, 23-27.

Baysal, A (Ed.). (2009).Beslenme [Nutrition]. (12.edition). Ankara: Hatipoğlu publishing house.

BeBİS (version 7.2). Ebispro for windows. Germany: Turkish Version Nutritional Information System.

Biagetti, C., Naspi, G., and Catassi, C. (2013). Health-Related Quality of Life in Children with Celiac Disease: A study based on the critical incident technique. Nutrients, 5, 4476-4485.

Çölyak ve görülme sıklığ1 [Celiac and celiac prevalence]. Retrieved from: http://beslenmehareket.saglik.gov.tr/. Access date:5/10/2015

Dalgıç, B, Sarı, S. and Baştürk, B. (2011). Turkish celiac study group. Prevalence of celiac disease in healthy Turkish school children. Am Journal Gastroenterol, 106, 1512-7.

Dall'Asta, C., Scarlato, A. P., Galaverna, G., Brighenti, F., \& Pellegrini, N. (2012). Dietary exposure to fumonisins and evaluation of nutrient intake in a group of adult celiac patients on a gluten-free diet. Molecular nutrition \& food research, 56(4), 632-640.

Demirçeken, G. F.. (2011).Gluten enteropatisi (çölyak hastalı̆̆ı): Klasik bir öykü ve güncel gelişmeler [Gluten enteropathy (celiac disease): A classic story and current developments]. Güncel Gastroenteroloji, 15(1), 58-72 .

Elsürer, R., Tatar, G., Şimsek, H., Balaban, Y. H., Aydinli, M. and Sokmensuer, C. (2005). Celiac disease in the Turkish population. Digestive Diseases and Sciences, 50(1), 136-142.

Fera, T., Cascio, B., Angelini, G., Martini, S. and Guidetti, C.S. (2003). Affective disorders and quality of life in adult coeliac disease patients on gluten-free diet. Eur Journal Gastroenterol Hepatol, 15, 1287-92

García-Manzanares, Á., \& Lucendo, A. J. (2011). Nutritional and dietary aspects of celiac disease. Nutrition in Clinical Practice, 26(2), 163-173.

Goodyer, L., Brown, L. J., \& Crowley, E. (2016). Celiac Disease Knowledge and Practice of Dietitians in Rural New South Wales, Australia. Food and Nutrition, 7, 874-883.

Green, P. H., Cellier, C. (2007). Celiac disease. New England Journal of Medicine, 357(17), 1731-1743.

Hall, N. J., Rubin, G. and Charnock, A. (2009). Systematic review: adherence to a gluten-free diet in adult patients with coeliac disease. Alimentary Pharmacology \& Therapeutics 30, 315-330.

Hallert, C., Graennoe, C., Hulten, S., Midhagen, G., Stroem, M. and Svensson, H, (1998). Quality of life of adult coeliac patients treated for 10 years. Scand Journal Gastroenterol, 33, 933-938.

Hallert, C., Grant, C., Grehn, S., Grännö, C., Hultén, S., Midhagen, G., and Ström, M. (2002). Evidence of poor vitamin status in coeliac patients on a gluten-free diet for 10 years. Alimentary Pharmacology \& Therapeutics, 16(7), 1333-1339.

Häuser, W., Gold, J., Stallmach, A., Caspary, WF. and Stein, J. (2007). Development and validation of the celiac disease questionnaire (CDQ), a disease-specific health-related quality of life measure for adult patients with celiac disease. Journal of Clinical Gastroenterology, 41(2), 157-66. 
Hauser, W., Gold, J., Stein, J., Caspary, WF. and Stallmach, A. (2006). Health related quality of life in adult coeliac disease in Germany - Results of a national survey. Eur Journal Gastroenterol Hepatol 18, 747-754.

Högberg L, Grodzinsky E, Stenhammar L. (2003). Better dietary compliance in patients with coeliac disease diagnosed in early childhood. Scand Journal Gastroenterol, 38(7), 751-4.

Kabbani, T. A., Goldberg, A., Kelly, C. P., Pallav, K., Tariq, S., Peer, A., and Leffler, D. A. (2012). Body mass index and the risk of obesity in coeliac disease treated with the gluten-free diet. Alimentary Pharmacology \& Therapeutics, 35(6), 723-729.

Kinsey, L., Burden, S.T., and Bannerman, E. (2008). A dietary survey to determine if patients with coeliac disease are meeting current healthy eating guidelines and how their diet compares to that of the British general population. European Journal of Clinical Nutrition, 62, 1333-1342.

Koehler, P., Wieser, H., \& Konitzer, K. (Eds.). (2014). Celiac disease and gluten: multidisciplinary challenges and opportunities. Academic Press.

Kupper, C. (2005). Dietary Guidelines and Implementation for Celiac Disease. Gastroenterology, 128, 121-127.

Lee A.R., Ng D.L., Diamond B., Ciaccio E.J. and Green P.H.R. (2012) Living with coeliac disease: survey results from the USA. Journal of Human Nutrition and Dietetics, 25, 233-238.

Marchese A, Klersy C, Biagi F, Balduzzi D, Bianchi PI, Trotta L, Vattiato C, Zilli A, Rademacher J, Andrealli A, Astegiano M, Michelini I, Häuser W. and Corazza GR. (2013). Quality of life in coeliac patients: Italian validation of a coeliac questionnaire. European Journal of Internal Medicine, 24, 87-91.

Miranda, J., Lasa, A., Bustamante, M. A., Churruca, I., and Simon, E. (2014). Nutritional differences between a gluten-free diet and a diet containing equivalent products with gluten. Plant Foods for Human Nutrition, 69(2), 182-187.

Moiseenko, E.E., Osipenko, M.F., Ageeva, T.A., Krotov, S.A. and Burbik, N.N. (2011) Different characteristics of quality of life in celiac disease patients. Terapevtichesii Arkhiv, 83(2), 25-28.

Mukherjee, R., Egbuna, I., Brar, P., Hernandez, L., McMahon, D., J., Shane, E., J., Bhagat, G., Green, P., H., R. (2010). Celiac disease: Similar presentations in the elderly and young adults. Digestive Diseases and Sciences, 55(11), 3147-3153.

Murray, J. A., Watson, T., Clearman, B., and Mitros, F. (2004). Effect of a gluten-free diet on gastrointestinal symptoms in celiac disease. The American Journal of Clinical Nutrition, 79, 669-73

Nadhem, O., N., Azeez, G., Smalligan, R., D., and Urban, S. (2015). Review and practice guidelines for celiac disease in 2014. Postgrad Medicine, 127(3), 259-265.

Norström, F., Lindholm, L., Sandström, O., Nordyke, K., and Ivarsson, A. (2011). Delay to celiac disease diagnosis and its implications for health-related quality of life. BMC Gastroenterology, 11(118), 1-8.

O'Leary, Wieneke, P., and Buckley, S. (2002). Celiac disease and irritable bowel-type symptoms. Am Journal Gastroenterol, 97, 1463-1467.

Olen, O., Montgomery, S.M., Marcus, C., Ekbom, A., and Ludvigsson, J.F. (2009) Coeliac disease and body mass index: a study of two Swedish genera population-based registers. Scandinavian Journal of Gastroenterology, 44(10), 1198-1206.

Onat, A., Hergenç, G., Can, G., Yüksel, H., Sansoy, V., Ünaltuna, N.E. ve diğerleri. (2009). Türk erişkinlerinde obezite, abdominal obezite, belirleyicileri ve sonuçları. A. Onat (Ed.). Türk halkının kalp sağlı̆̆ı sırrına ışık tıbba önemli katkı (s. 106 İstanbul: Cortex İletişim Hizmetleri A.Ş

Paarlahti, P., Kurppa, K., Ukkola, A., Collin, P., Huhtala, H., Mäki, M., and Kaukinen, K. (2013). Predictors of persistent symptoms and reduced quality of life in treated coeliac disease patients: A large cross-sectional study, BMC Gastroenterology, 13(75), 1-8.

Pulido, O., Zarkadas, M., Dubois, S., Macisaac, K., Cantin I., La, Vieille, S., Godefroy, S. and Rashid, M. (2013). Clinical features and symptom recovery on a gluten-free diet in Canadian adults with celiac disease. Can Journal Gastroenterol, 27(8), 449-53.

Reguła, J., Śmidowicz, A. (2014). Share of dietary supplements in nutrition of coeliac disease patients. Acta Scientiarum Polonorum Technologia Alimentaria, 13(3), 301-307.

Reilly, N. R., Aguilar, K., Hassid, B. G., Cheng, J., DeFelice, A. R., Kazlow, P., and Green, P. H. (2011). Celiac disease in normal-weight and overweight children: clinical features and growth outcomes following a gluten-free diet. Journal of Pediatric Gastroenterology and Nutrition, 53(5), 528-531.

Sáez, R. L., Fuentes, A. D., Pérez, M. I., Álvarez, M. N., Niño, G. P., and De Francisco, G. R. (2011). Differences between pediatric and adult celiac disease. Revista Española de Enfermedades Digestivas, 103, 238-244.

Samasca, G., Sur, G., Lupan, I., and Deleanu, D. (2014). Gluten-free diet and quality of life in celiac disease. Gastroenterology and Hepatology From Bed to Bench, 7(3), 139-143.

Sapone, A., Bai, J.C., Ciacci, C., Dolinsek, J., Green, P., H., R., Hadjivassiliou, M., Kaukinen, K., Rostami, K., Sanders, S., D., Schumann, M., Ullrich, R., Villalta, D., Volta, U., Catassi, C., and Fasano, A. (2012). Spectrum of gluten-related disorders: consensus on new nomenclature and classification, BMC Medicine, 10(13), 1-12.

Saturni, L., Ferretti, G., and Bacchetti, T. (2010). The gluten-free diet: Safety and nutritional quality. Nutrients, 2(1), 16-34. Semeraro, L. A., Barwick, K. W., and Gryboski, J. D. (1986). Obesity in celiac sprue. Journal of clinical gastroenterology, 8(2), 177-180.

Singh, I., Agnihotri, A., Sharma, A., Verma, A. K., Das, P., Thakur, B., \& Makharia, G. K. (2016). Patients with celiac disease may have normal weight or may even be overweight. Indian Journal of Gastroenterology, 35(1), 20-24. 
Thompson, T., Dennis, M., Higgins, L., Lee, A., \& Sharrett, M. (2005). Gluten-free diet survey: are Americans with coeliac disease consuming recommended amounts of fibre, iron, calcium and grain foods? Journal of Human Nutrition and Dietetics, 18(3), 163-169.

Türkiye Beslenme ve Sağlık Araştırması (2010) [Turkey Nutrition and Health Survey (2010)]. Ankara: Ministry of Health Publications.No:931

Valente, F., X., do Nascimento-Campos, T., de Sousa Moraes, L.F. Hermsdorff, H., H., M., de Morais Cardoso, L., and Helena Maria Pinheiro-Sant'Ana, H. M. (2015). B vitamins related to homocysteine metabolism in adults celiac disease patients: a cross-sectional study. Nutrition Journal, 14(110), 1-7.

Whitehead, C. (2013). Obesity and coeliac disease: possible effects of the gluten-free diet. Gastrointestinal Nursing, 11(3), 31-36.

World Health Organization regional office for Europe body mass index - BMI (2018). Retrieved from: http://www.euro.who.int/en/health-topics/disease-prevention/nutrition/a-healthy-lifestyle/body-mass-index-bmi World Medical Association (2001). World Medical Association Declaration of Helsinki. Ethical principles for medical research involving human subjects. Bulletin of the World Health Organization, 79(4), 373.

Zampieron, A., Daicampi, C., Martin, A., and Buja, A. (2011). Quality of life in adult celiac disease in a mountain area of northeast Italy. Gastroenterology Nursing, 34(4), 313-319.

Zarkadas, M., Cranney, A., Case, S., Molloy, M., Switzer, C., Graham, I.D., Butzner, J.D., Rashid, M. Warren, R.E., and Burrows, V. (2006). The impact of a gluten-free diet on adults with coeliac disease: results of a national survey, Journal of Human Nutrition and Dietetics, 19, 41-49.

Zarkadas, M., Dubois, S., MacIsaac, K., Cantin, I., Rashid, M., Roberts, K. C., and Pulido, O. M. (2013). Living with coeliac disease and a gluten-free diet: A Canadian perspective. Journal of Human Nutrition and Dietetics, 26(1), 10-23. 